\title{
DISTRIBUTION OF SHEATH-TAILED BATS (EMBALLONURIDAE) IN BUNDELKHAND REGION OF UTTAR PRADESH
}

\author{
Shaktivardhan Singh*1, Pawan Kumar Misra' ${ }^{1}$ and V. Elangovan ${ }^{1}$ \\ 'Department of Zoology \\ Babasaheb Bhimrao Ambedkar University, Lucknow-226 025, India. \\ Email: shaktivardhansingh7@gamil.com
}

\begin{abstract}
The family Emballonuridae consist 54 species and distributed throughout the world. Six species of genus Taphazous were found in India. There was no proper report on distribution of Taphozous genus from Bundelkhand region. Therefore, an extensive survey was carried out in Bundelkhand region of Uttar Pradesh to explore the distribution of the genus Taphazous. A total of six roosts were recorded, which occupied by Taphazous species. Taphazous perforatus found only in Kulpahar Mahal, while rest five roosts were occupied by Taphazous nudiventris. T.nudiventris \& T. perforatus found in historical monuments made up of red stone, where the average roost height from the ground is $26.9 \pm 3.78$ (feet) and the average humidity and light intensity $56.2 \pm 14.13(\%)$ and $1.4 \pm 1.34$ (lux) are respectively. The highest population was in Jhansi Palace (120 to 460 individuals), while lowest one was in Kalinjar fort (12 to 25 individuals). The roosts protected by Archaeological Survey of India. Due to human activity, the roosts were destroying day by day, by erection of nets at the entrance and light source on the roost. Therefore, need a proper conservation otherwise; there will be a great loss.
\end{abstract}

KEYWORDS: Bundelkhand, Distribution, Emblarunidae, Roost, Taphozous

\section{INTRODUCTION}

Emballonuridae or sheath-tailed bat is a medium-sized microbat commonly known as the tomb bat. This genus Taphozous is found arid and semi-arid region of Africa, Asia and Australia, and consists of 54 species, under 14 genera $^{1}$. Out of all known species of Taphozous, six species found in India and they are T. longimanus or longwinged tomb bat ${ }^{2}$, found in Assam, Maharashtra, Kerala, Nagaland ${ }^{3,4,5,6,7}, \boldsymbol{T}$. nudiventris or naked-rumped tomb $\mathrm{Bat}^{8}$, found in Madhya Pradseh and Delhi ${ }^{9,10,11,12}$, T. perforatus or egyptian tomb bat ${ }^{13}$, presently not recorded in India ${ }^{14}, T$. theobaldi or theobald's tomb bat ${ }^{15}$, found in Madhya Pradesh ${ }^{12}$, T. melanopogon or black- bearded tomb bat ${ }^{16}$, found in Andaman and Nicobar UT, Madhya Pradesh, Andhra Pradesh, Delhi, Kerala ${ }^{11,12,17,18,19}$ and $T$. saccolaimus or naked-rumped pouched bat ${ }^{20}$ found in Madhya Pradesh, Maharashtra, Assam, Kerala ${ }^{10,21,22,23}$.

Taphozous nudiventris largely occurs in tropical and subtropical grasslands, savannahs and shrub lands, as well as in more arid habitats including deserts and xeric shrub lands, from north-western and sub-Saharan Africa through Egypt and the Middle East to Pakistan, India and Myanmar 24, 25. This species was described as being closely associated with rocky outcrops and hills and, to a lesser extent, with buildings, where it occupies a multitude of roosts such 
as caves, crevices of rocks, narrow fissures, ancient tombs and wells ${ }^{24}$. Taphozous perforatus prefer mostly thorn forest area ${ }^{26}$. In India it is mostly found in more arid area $^{27}$. Day roosts of $T$. perforatus are mainly found in manmade building, disused well ${ }^{28}$, and ruined building ${ }^{29}$.

T. longimanus found in a variety of roosts because their wide tolerance to climate like arid zone of Gujarat to humid region Sri Lanka, and its day roost includes caves, wells and old buildings ${ }^{28}$. They mostly live unisexual group only breeding season male and female live together ${ }^{30} . T$. melanopogon prefer forest and hilly area where fresh water is present ${ }^{28}$. Daytime they usually roost in temples caves and ruins ${ }^{31}$. Males and females live separate in different roost or in same roosting place ${ }^{32}$. About roosting of $T$. theobaldi less information is available, and it roosted mainly in natural cave $^{28}$. T. saccolaimus mostly found on tree roots in kittul and Areca nut palms trees, and it is some time roosting in roof of building ${ }^{33}$. Male and female live together in small colonies consist of five to six individual $^{34}$.

A very few studies have been carried out on distribution, roost selection and ecological importance of emballonuridae bat in Bundelkhand region of Uttar Pradesh, Elangovan and Kumar ${ }^{11}$. Chaturvedi et. al..$^{35}$ studied on acoustic morphological based identification of Microchiropteran species in Chitrakoot. There is no report are available on the distribution of Taphozous species. in Bundelkhand regions, therefore it creates a gap in this area.

The Bundelkhand region comes under the state of Uttar Pradesh and Madhya Pradesh, and the region lies between the Indo-Gangetic plain to North and the Vindhya Range to South. Bundelkhand faced extreme condition in all seasons, in winter temperature goes up to $2^{\circ} \mathrm{C}$, and while in summer it faced up to $49^{\circ} \mathrm{C}$. It is gently sloping upland, distinguished by barren hilly terrain with sparse vegetation. It contains many historical monuments and caves. Total 3503 historical monuments found in India which is under ASI out of which 36 monuments found in Bundelkhand region of U.P. The historical monuments, caves and tombs are main reservoirs of bats $^{24}$. The species of Taphozous mainly found in historical monuments and tombs, that's why they commonly known as a tomb bat. The Bundelkhand region is best suited habitats for those bats which preferred to roost in semi dried condition and in monuments or abandoned building. Thus, the study was carried out to fulfill the lacuna on distribution of sheath-tailed bats in Bundelkhand region of up.

\section{MATERIALS AND METHODS}

\section{Study Area}

Bundelkhand region of Uttar Pradesh consist of seven districts namely Chitrakoot, Banda, Mahoba, Hamirpur, Jalaun, Jhansi and Lalitpur which hold about 29 thousand square kilometer area. It is a largest arid zone of Uttar Pradesh. Periodical surveys were carried out in all districts at residential 
and non-residential areas along with forest, hill, agriculture land or terrain by visual observation to assess the distribution of Emballonuridae bats. Bat detector also used for acoustic identification of bats as well as to locate their day roosts sites which include abandoned buildings, temples, caves, crevices, and monuments. The location of roost was taken with the help of mobile GPS (Google earth). Population of bats was studied by visual observation at the time of emergence by following Easterla \& Watkins $^{36}$; Humphrey \& Cope ${ }^{37}$; and Swift ${ }^{38}$. Photographs of each roost site were taken using Nikon D53 with 18 - 55 mm Nikkor lens. The population of bats was accessed by photographic count ${ }^{39}$.

Bats were captured using mist nets as well as hoop nets for identification and released at the site of capture. Bats were identified using the key of Bates and Harrison $^{40}$. The Guidelines of American Society of Mammalogy were followed for capturing of bats ${ }^{41}$.

\section{RESULTS AND DISCUSSION}

A total of six species of Taphozous found all over India, out of which two species as: $T$. nudiventris and $T$. perforatus were recorded from the study sites. There was no earlier extensive study were available on this region. A total of 24 sites were visited from March 2019 - February 2020 in Bundelkhand region in search of bat roost. Out of which five sites (Fig. 1) were found that's occupied by two species of Emballonuridae bats namely $T$. nudiventris and T. perforatus.

In Jhansi districts Barua - Sagar fort (25 $\left.22^{\circ} 31^{\prime \prime} \mathrm{N} 78^{\circ} 44^{\prime} 28^{\prime \prime} \mathrm{E}\right)$ and Jhansi fort $\left(25^{\circ} 27^{\prime} 28^{\prime \prime} \mathrm{N} 78^{\circ} 34^{\prime} 32^{\prime \prime} \mathrm{E}\right)$ roosts were resided by $T$. nudiventris. Barua - Sagar fort is situated near Orchha while Jhansi Fort situated at center of Jhansi city. Kalinjar fort ( $24^{\circ} 59^{\prime} 46^{\prime \prime} \mathrm{N} 80^{\circ} 29^{\prime} 04^{\prime \prime} \mathrm{E}$ ) is situated in Banda district that's $70 \mathrm{Km}$ from the Banda city. These three Forts are protected by Archaeological Survey of India (ASI).

In Mahoba district two roots were found one at Kulpahar Mahal (25 $18^{\prime}$ 00" $\left.\mathrm{N} 79^{\circ} 37^{\prime} 21^{\prime \prime} \mathrm{E}\right)$ and second one at Joran

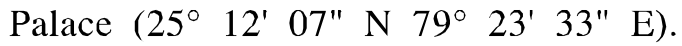
Kulpahar Mahal is situated in center of Kulpahar town while Joran Palace in Joran village that's share the boundary of Uttar Pradesh (U.P.) and Madhya Pradesh (M.P.).

The morphological measurements of T. nudiventris and T. perforatus are given in Table 1. The average forearm of $T$. nudiventris $73 \pm 2.02 \mathrm{~mm}$ and $T$. perforatus was $67 \pm 4.04 \mathrm{~mm}$. A well-developed gular sac (Fig. 2a) is clearly visible at the chin region of $T$. nudiventris and area of gular sac was hairless. A radio-metacarpal pouch (Fig. 2b) present on the joint of forearm and metacarpal; it is a sac like gap, and tragus is club shaped (Fig. 2c). Hairs on body surface were limited and absent on wings. Hairs are pale brown in colour, paleness also present along shore of the body. A small bunch of hair found just below of forearm and metacarpal joint, which was white in colour.

T. perforatus possess buffy hair on 

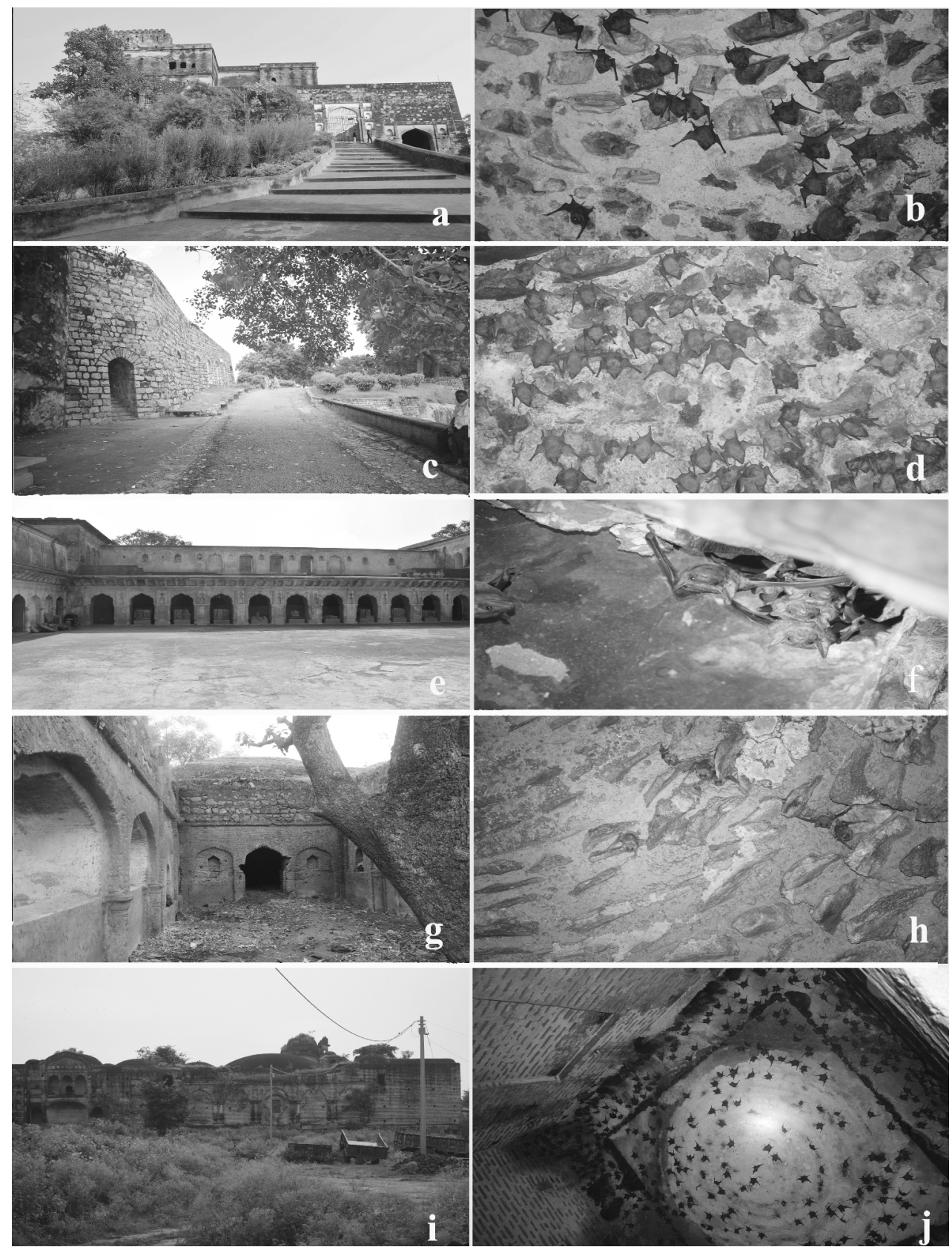

Fig.-1. Five roosts sites of Taphozous nudiventris and T. perforatus found in Bundelkhand region: Barua Sagar Fort (a), Jhansi Fort (c), Kalijar Fort (e), Kulpahar Mahal (g), Joran Palace (i), colony of $T$. perforatus $(\mathrm{h})$ and colony of $T$. nudiventris $(\mathrm{b}, \mathrm{d}, \mathrm{f}, \mathrm{j})$. 

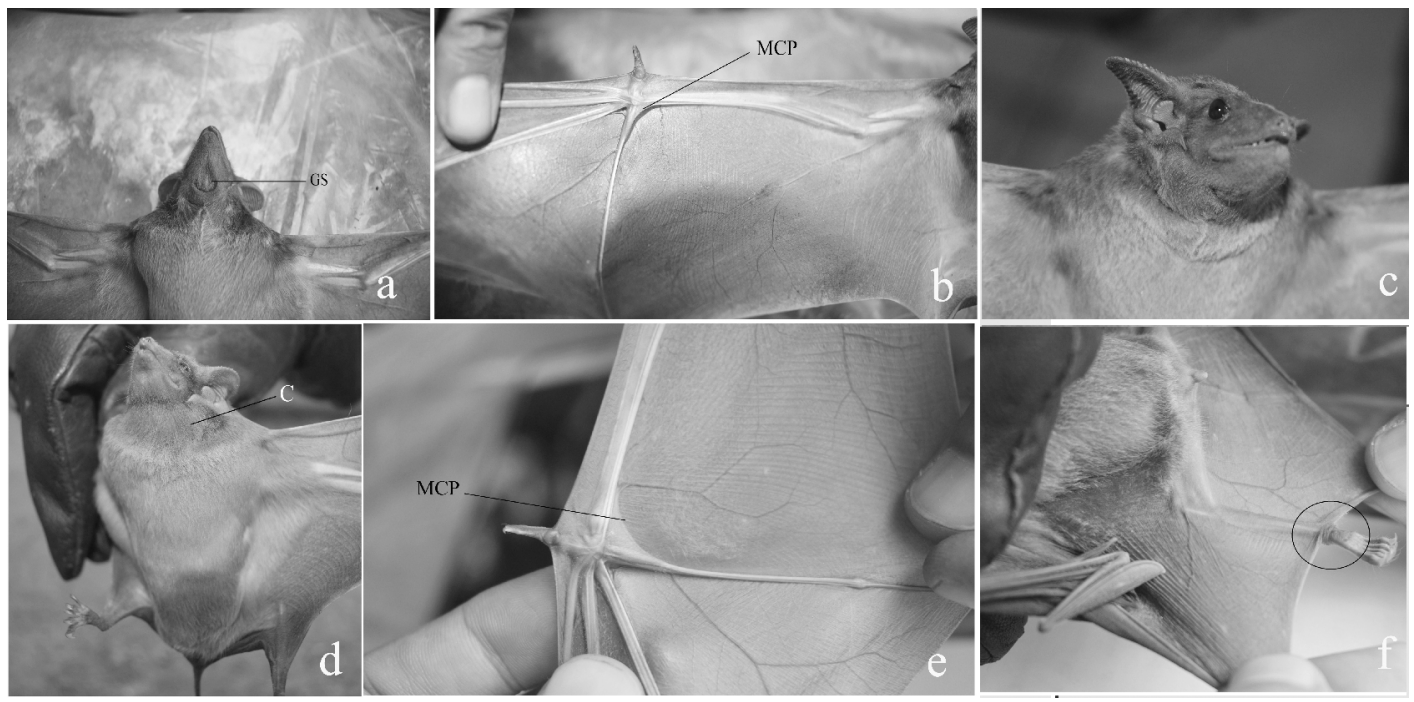

Fig.-2. External morphology and taxonomical characteristics of Taphozous: Gular Sac (GS) (a), Metacarpal pouch (MCP) (b), Tragus (T) (c) of T. nudiventris. Buffy hairs on Collar (C) (d), Metacarpal pouch (MCP) and a small bunch of hairs (in the circle) (e), wings attached to Tibia (in the circle) (f) of $T$. perforatus.

Table-1. Morphological measurements of Taphozousnudiventris and Taphozousperforatus. The values are given as Mean \pm SD

\begin{tabular}{|l|c|c|}
\hline Morphological measurement $(\mathbf{m m})$ & T. nudiventris $(\mathbf{n}=\mathbf{1 2})$ & T. perforatus $(\mathbf{n}=\mathbf{7})$ \\
\hline Head Bodylength & $93 \pm 31.96$ & $83 \pm 7.79$ \\
\hline Head length & $33 \pm 1.36$ & $27 \pm 2.03$ \\
\hline Tail length & $20 \pm 2.71$ & $17 \pm 2.48$ \\
\hline Ear length & $14 \pm 2.61$ & $16 \pm 2.45$ \\
\hline Ear width & $10 \pm 2.22$ & $10 \pm .86$ \\
\hline Tragus & $5 \pm 0.12$ & $5 \pm 1.07$ \\
\hline Forearm & $73 \pm 2.02$ & $67 \pm 4.04$ \\
\hline $5^{\text {th }}$ metacarpal & $44 \pm 2.78$ & $39 \pm 2.59$ \\
\hline $4^{\text {th }}$ metacarpal & $54 \pm 2.12$ & $49 \pm 2.88$ \\
\hline $3^{\text {rd }}$ metacarpal & $66 \pm 2.49$ & $60 \pm 3.16$ \\
\hline $2^{\text {nd }}$ metacarpal & $60 \pm 2.12$ & $57 \pm 3.64$ \\
\hline Wing span & $441 \pm 20.58$ & $419 \pm 32.25$ \\
\hline Hind arm & $32 \pm 2.00$ & $25 \pm 1.11$ \\
\hline
\end{tabular}


throat region (Fig. 2d) which is brown in colour. Wings attached to the tibia of hind arm (Fig. 2f) and some hair also present in feet. Hairs present on all over body surface and some hairs also on wings surface which are white gray in colour. The hairs of ventral body surface mouse gray in colour, while hairs of upper body surface (dorsal surface) pale gray in colour. A sac which called radio metacarpal pouch, found on the junction of forearm and metacarpal (Fig. 2e), and Metacarpal pouch of $T$. perforatus was more developed than T. nudiventris. A small bunch of white colour hair present just below of radio metacarpal pouch (Fig. 2e).

\section{Barua-Sagar fort}

The roost of $T$. nudiventris was found in the Barua-Sagar fort. The population varied over seasons during summer it was 130 and reduced to a few individuals during winter. T. nudiventris occupied the ground floor of a six-story building made up of red-stone (Fig. 1a). They occupied the attic of a dark room at about 24 feet (Fig. 1b). There are two open entrances for the entry of room and both entrances are $7 \mathrm{X} 4$ feet in height and width. The temperature, humidity and light intensity were $27^{\circ} \mathrm{C}, 47 \%$ and zero lux, respectively. They occupy the attic and on wall surface during summer, and prefer to roost inside the tunnel or crevice during winter. There is a big pond in one side of the building and another side is occupied by human settlement. The fort is full of garden with different flower.

\section{Jhansi fort}

The fort was named on Queen Jhansi, who was a greatest freedom fighter. In Jhansi fort two roosting sites of $T$. nudiventris were found (Fig. 1d), one is in Panch Mahal (upper side front of panchmahal), and another near to Kadak Bijali Toap. Building of roost made up of stone and circular in shape (Fig. 1c). Roof of room is tomb shape and heights of both rooms are 21 feet from the ground and area of both rooms are same 324 feet. Both rooms possess single entrance, and height of entrance was seven feet. The population was 460 individuals in Panch Mahal while 320 individuals in Kadak Bijali Toap. Temperature varies from $22^{\circ} \mathrm{C}$ to $29.5^{\circ} \mathrm{C}$ and humidity varies from 45 to $94 \%$. Light intensity was zero lux in roost.

\section{Kalinjar fort}

T. nudientris were found roosting in Kalinjar fort, roost is made up of stone and the shape of room was rectangle (Fig. 1e). In the roof of building there were many deep crevices, in which $T$. nudientris were residing (Fig. 1f). A total of 25 individuals were recorded during the field visit. Total area of roost was 49 feet and height of roost was 15 feet. The roost consists of two open entrances and height and width of entrances were nine and three feet respectively. Temperature and humidity were $32^{\circ} \mathrm{C}$ and $51 \%$ respectively, and light intensity three lux.

\section{Kulpahar Mahal}

It is only roost where $T$. perforatus 
found. Monument was situated near a pond and surround by human colony. There are three rooms in the Mahal, out of which one room occupied by T. perforatous. Bat found on attic and crevices of roost (Fig. 1h). The total population was 32 individuals. Monument was made up of stone (Fig. 1g). There was a single open entrance in the roosts. The roost was circle in shape and roof tomb in shape. The total area of roost was 196 square feet. The height of roost was 24 feet. Temperature and humidity at the time of visit is $23^{\circ} \mathrm{C}$ and $54 \%$ respectively, and light intensity under the roost was zero lux.

\section{Joran Palace}

In Joran Palace T. nudiventris were roosting. The Palace is surrounded three side by agriculture field, while in front of the gate, there is bushy tree (Fig. 1i). At the front of the monuments a small water canal is flowing. Monument mostly ruined, only few rooms were in such condition in which bats can live. T. nudiventris were roosting in a room which attached with a tunnel like hall (Fig. 1j). There are two open entrances for roost site. Approximate, population of colony was 296 individuals. The roof of room was rounded in shape, while roof of hall was tomb shape; height of roost was 23 feet. Whole palace is made up of by red stone. The roosting site was also shared by human activity and cattle. Peoples are using it for storing of cow dung (upples) and for caging of animals. Temperature of roost at the time of visit was $26.5^{\circ} \mathrm{C}$ and humidity $81 \%$. The light intensity of room was zero while of hall was two lux.

Earlier report of $T$. nudiventris distribution was only from Bhuj, Gujarat ${ }^{42}$ and from Agra $^{28}$ in U.P. Taphozous nudiventris were found roosting in crevices of roof in the monument where light intensity was zero lux. A noticeable observation was recorded that T. nudiventris shared roost with Rhinopoma microphyllum and Rousettus leschenaultii. In Barua Sagar the average roost height from the ground was 26.9.the average humidity and light intensity was $56.2 \%$ and 1.4 lux respectively and a common pattern was found that in summer T. nudiventris occupied same place where $R$. leschenaultii found in winter. The colony of T. nudiventris mostly consists of males, and few females.

Earlier distribution of $T$. perforatus only reported from Rajasthan ${ }^{43,44}$, Gujarat ${ }^{28,}$ ${ }^{29}$, Madhya Pradesh ${ }^{27}$, besides that's there are no any reports are available on distribution. It is first report of $T$. perforatus from Uttar Pradesh. T. perforatus were only found in Kulpahar, where light intensity was zero. Those roost which maintained temperature between 23 to $30{ }^{\circ} \mathrm{C}$ whole year, bat were available whole year and almost with constant population, but where temperature go down below $23^{\circ} \mathrm{C}$ bat move or go hibernation and number of individuals reduced very sharply.

The population of these species is declining day by day due to human activity that destroying their roost. Human are removing bats from their roosting and killing them by smoke. The monuments protected 
by ASI also vacating the roosts of bats by putting the nets on entrance and installing the high intensity light beneath the roosts. The population of these two species declining very sharply and if these practices continue, no any steps were taken for the conservation one day we lost a novel creature which provide many services to us. They provide highly important ecological services such as insect-pest predation, due to these functional roles and their sensitivity to environmental change; bats are useful bioindicators of local as well as landscape-level disturbances and change ${ }^{45,46,47}$. Tophozous species feed on variety of insect, most preferred food items of $T$. perforatus is moths followed by Isoptera, Coleoptera, Orthoptera as well as Hemiptera, Neuroptera, Hymenoptera and Diptera ${ }^{48}$ while T. melanopogon preferred coleopteran, Homoptera, Lepidoptera, Hemiptera, Orthoptera, Odonata and araneidae ${ }^{49}$. The diet of these bat species clearly indicates that's they good biological insect pest controller. The order Lepidoptera, coleopteran, Diptera etc. are harmful for agriculture and garden plant ${ }^{50}$. Therefore, there is need of proper conservation of this species. Otherwise, one day will come when we loss this species.

\section{ACKNOWLEDGEMENT}

We thank the Archaeological Survey of India for permitting us in the monuments. The financial assistance of Science \& Engineering Research Board, New Delhi, through a Major research project (EEQ/
2018/000104) to VE is acknowledged.

\section{CONFLICT OF INTEREST}

The authors declare that they have no conflict of interest.

\section{REFERENCES}

1. Burgin, C.J., J.P. Colella, P.L. Kahn and N.S. Upham, 2018. How many species of mammals are there? J. Mammal., 99(1): 114.

2. Hardwicke, T., 1825. Description of a new species of sheath-tailed bat (Taphozous) found in Calcutta. Transactions Linn. Soc. Lond., 14: 525-526.

3. Sinha, Y.P., 1999. Bats of the Siju cave, South Garo Hills, Meghalaya, India: Taxonomy and Bionomics. Rec. Zool. Surv. India, 97(1): 101-122.

4. Korad, V.S., M.C. Gaikwad and K.D. Yardi, 2005. Extension in the distribution of Burmese whiskered bat, Myotis montivagus (Dobson, 1874) in the Northern Western Ghats range, Maharashtra, India. Rec. Zool. Surv. India, 104(3-4): 91-97.

5. Pradhan, M.S. and S.S. Talmale, 2008. Mammalia, In: Fauna of Lonar Wildlife Sanctuary. Conservation Area Series, Zool. Surv. India, 37: 17-28.

6. Gaikwad, M.C., S.S. Narwade, K.M. Fartade and V.S. Korad, 2012. A review of the distribution of bats in South-Western region of Deccan, Maharashtra-India and conservation recommendations. Taprobanica, 4(1): 27-36.

7. Boro, A., P.K. Saikia and U. Saikia, 2018. New records of bats (Mammalia: Chiroptera) from Assam, northeastern India with a distribution list of the bat fauna of the state. J. Threat. Taxa, 10(5): 11606-11612.

8. Cretzschmar, P.J., 1826. Atlas zu der reiseimno“ rdlichen Afrika, von Eduard Ru" ppell. 1. Abth. Zoologie. Hrsg. von der Senkenbergischen Naturforschenden 
Gesellschaft. H. L. Bro"nner, Frankfurt am Main.

9. Srinivasulu, C. and B. Srinivasulu, 2007a. Bats of Delhi: An update. Bat. Net.,8(1-2): 30-31.

10. Pradhan, M.S. and S.S. Talmale, 2012. Mammalia. Fauna of Maharashtra, State Fauna Series, Published by Zool. Surv. India, 20(1): 21-145.

11. Elangovan, V., V. Mathur, M. Kumar and Y.S. Priya, 2018. Diversity and Conservation of Chiropteran Fauna. In: Sivaperuman C., Venkataraman K. (eds), Indian Hotspots. Springer, Singapore, pp. 57-87.

12. Talmale, S.S., 2017. Taxonomic Studies of Small Mammals (Scandentia, Rodentia, Soricomorpha and Chiroptera) of Madhya Pradesh, Rec. Zool. Surv. India, 383: 1-108.

13. Geoffroy, E., 1818. "Description des mammifères qui se trouventen Égypt". Description de l'Égypte: Histoire Naturellei Paris, 3: 126-128.

14. Saikia, U., 2018. A review of Chiropterological studies and a distributional list of the Bat Fauna of India Rec. Zool. Surv. India, 118(3): 242-280.

15. Dobson, G.E., 1872. Notes on the Asiatic species of Taphozous Geoff. Proceedings Asiat. Soc. Bengal, 151-154.

16. Temminck, C.J., 1841. "Monographies de mammalogie". 2. G. Dufour et E. d'Ocagne, 1841: 287-289.

17. Srinivasulu, B., C. Srinivasulu and B. Ravinder, 2005. Occurrence of Lesser Mouse-tailed Bat Rhinopoma hardwickii Gray, 1831 and Blackbearded Tomb Bat Taphozous melanopogon Temminck, 1841 (Mammalia: Chiropetra: Rhinopomatidae and Emballonuridae) in Adilabad district, A.P. Bat. Net., 6(2): 2-3.

18. Srinivasulu, C. and B. Srinivasulu, 2007b. First specimen-based record of Egyptian free-tailed bat Tadarida aegyptica E. Geoffroy, 1818 (Chiroptera: Molossidae) from Andhra Pradesh, India. Zoos. Print J., 12: 2943.

19. Aul, B., 2014. Record of Tylonycteris pachypus
(Lesser Bamboo Bat) from Andaman Islands. Amb. Sci., 1(1): 44-46.

20. Temminck, C.J., 1838. "Taphozoüs saccolaimus". Tijdschrift Voor Natuurlijke Geschiedenis En. Physiologie. 5: 14.

21. Ghose, R.K. and T.P. Bhattacharya, 1995. Mammalia. In: Fauna of Kanha Tiger Reserve, Madhya Pradesh, Fauna of Conservation Areas No. Zool. Surv. India, 7: 93-117.

22. Boro, A. and U. Saikia, 2015. The Horsfield's Myotis, Myotis horsfieldii (Temminck, 1840) (Chiroptera: Vespertilionidae); an addition to the bat fauna of Assam. Small Mamm. Mail, 7(1): 13-14.

23. Ali, A., 2016. New distributional record of pouch-bearing bat Saccolaimus saccolaimus Temminck, 1838 from Assam, India. Small Mamm. Mail, 8(1):14.

24. Happold, M., 2013. Taphozous nudiventris Naked-rumped tomb bat. In: M. Happold, \& D. C. D. Happold (eds.), Mammals of Africa. Volume IV: Hedgehogs, shrews and bats Bloomsbury Publishing, London, U.K., 434435.

25. Bonaccorso, F., 2019. Family Emballonuridae (sheath-tailed bats). In: D. E. Wilson, \& R. A. Mittermeier (eds) Handbook of the mammals of the world. Volume 9: Barcelona: Lynx Edicions Bats, 334-373.

26. Siddiqi, M.S., 1961. Checklist of mammals of Pakistan with particular reference to the Mammalian Collection in the British Museum (Natural History), London. Biologia, 7(1-2): 93-225.

27. Khajuria, H., 1965. Distribution of the tomb bat, Taphozous perforatus peforatus E. Geoffroy. J. Bombay Nat. Hist. Soc., 61: 682.

28. Brosset, A., 1962a. The bats of central and western India. Part I, J. Bombay Nat. Hist. Soc., 59: 583-624.

29. Sinha, Y.P., 1981. Studies on bats of Gujarat. Rec. Zool. Surv. India, 78: 101-112.

30. Krishna, A. and C.J. Dominic, 1985. Observation 
on the social organisation and sex ratio in three species of Indian bats. J. Bombay Nat. Hist. Soc., 82(1): 24-29.

31. Hill, J.E., 1967. The bats of the Andaman and Nicobar Island. J. Bombay Nat. Hist. Soc., 64(1): 1-9.

32. Brosset, A., 1962b. La reproduction des Chiropteres de l'ouestet du centre de l'Inde. Mammalia, 26(2): 176-213.

33. Phillips, W.W.A., 1980. Manual of the mammals of Sri Lanka Part 1. Wildl. Nat. Prot. Soc. Sri Lanka, 1-116.

34. Lekagul, B. \& J.A. McNeely, 1977. Mammals of Thailand. Assoc. Conserv. Wildl., 758.

35. Chaturvedi, S.K., S. Singh and A.K. Tiwari, 2018. Acoustic \& morphology-based identification of microchiropteran species in Chitrakoot district, Uttar Pradesh, India. Int. J. Zool. 3(1): 352-357.

36. Easterla D.A. and L. Watkins, 1970. Nursery colonies of evening bats (Nycticeius humeralis) in north-western Missouri and South-Western Lowa. Trans. Missouri Acas. Sci., 4: 110-117.

37. Humphrey, S.R. \& J.B. Cope, 1976. Population ecology of the little brown bat, Myotis lucifugus, in Indian and north-central Kentucky. Spec. Publ. Am. Soc. Mamm., 4: 1-79.

38. Swift, S.M., 1980. Activity pattern of Pipistrelle bats (Pipistrellus pipistrellus) in north-east Scotland. J. Zoo. Lond., 190: 285-295.

39. Thomas, D.W. and R.K. Laval, 1988. Survey and census method. In: T.H. Kunz (eds) ecological and behavioural method for study of bats. Smithsonian institution press, Washington D.C., 77-89.

40. Bates, P. J. J. and D. L. Harrison, 1997. Bats of the Indian Subcontinent. Harrison Zoological Museum Publication, 258.
41. Sikes, R.S., L.G. William and the Animal Care \& Use Committee of the American Society of Mammalogists, 2011. Guidelines of the American Society of Mammalogists for the use of wild mammals in research. $J$. Mammal., 92(1): 235-253.

42. Wroughton, R.C., 1912. Report Mammal Survey of India. J. Bombay Nat. Hist. Soc. 21(3): 820-851.

43. Sinha, Y.P., 1980. The bats of Rajasthan: taxonomy and zoogeography. Rec. Zool. Surv. India, 76(1-4): 7-63.

44. Advani, R., 1982. Distribution and status of Chiroptera species in Rajasthan, India. Säug Mitt. 30(1): 49-52.

45. Fenton, M.B., L. Acharya, D. Audet, M.B.C. Hickey, C. Merriman, M.K. Obrist and D.M. Syme, 1992. Phyllostomid bats (Chiroptera: Phyllostomidae) as indicators of habitat disruption in the neotropics. Biotropica, 24: 440-446.

46. Jones, G., D.S. Jacobs, T.H. Kunz, M.R. Willig and P.A. Racey, 2009. Carpe noctem: the importance of bats as bioindicators. Endanger. Sp. Res., 8: 93-115.

47. Medellin, R.A., M. Equihua and M.A. Amin, 2000. Bat diversity and abundance as indicators of disturbance in neotropical rainforests. Conserv. Biol., 14: 1666-1675.

48. Rydell, J. and D.W. Yalden, 1997. The diets of two high-flying bats from Africa. J. Zool., Land. 242: 69-76.

49. Srinivasulu, B. and C. Srinivasulu, 2005. Diet of the black bearded tomb bat Taphozous melanopogon, Temminck, 1941 (Chiroptera: Emballonuridae) in India. Zoos. Print J., 20(8): 1935-1938.

50. Kollar, J., 2007. The harmful entomofauna of woody plants in Slovakia. Acta Entomol. Serbica, 12 (1): 67-79. 